\title{
PERPUSTAKAAN GARDA BANGSA: \\ KOLEKSI LOCAL CONTENT SEBAGAI KEKUATAN UTAMA MEMBANGUN KHASANAH \\ PERADABAN BANGSA MELALUI IMPLEMENTASI KEBIJAKAN PUBLIK UNDANG-UNDANG NOMOR 4 TAHUN 1990 TENTANG SERAH SIMPAN KARYA CETAK DAN KARYA REKAM
}

\author{
Bakhtiyar \\ Jurusan Perpustakaan dan Sain Informasi \\ Fakultas Ilmu Sosial Dan Ilmu Politik Universitas Wijaya Kusuma Surabaya \\ Email : bakhtiyar.fisipuwks@gmail.com
}

\begin{abstract}
ABSTRAK
Tujuan kajian ingin mengetahui : (1). Arti penting koleksi local content Jawa Timur ((2). Implementasi Undang-Undang Nomor 4 Tahun 1990 terhadap koleksi local content di perpustakaan umum daerah di Provinsi Jawa Timur. (3). Kendala dalam pelaksanaannya. Obyek dan ruang lingkup kajian berorientasi perwujudan manajemen implentasi Undang-Undang Nomor 4 Tahun 1990. Pendekatan kajian adalah historical approach). Metode kajian digunakan library research dan dilakukan analisa diskriptif kualitatif, content analysis serta oservasi Hasil kajian adalah: (1). Koleksi local content memiliki arti penting bagi identitas daerah dengan khasanah budaya bercorak kekhasan daerah, yang memberikan nilai-nilai inspiratif dan kreatif mendorong rasa kebanggaan terhadap budaya daerah. (2). Pelaksanaan Undang-Undang Nomor 4 Tahun 1990 di Perpustakaan Umum Daerah di Provinsi Jawa Timur, secara umum adalah cukup baik. (3). Kendala dalam implementasi Undang-Undang tersebut meliputi: (a). Belum adanya Peraturan Daerah tentang serah simpan karya cetak dan rekam. (b). Dibutuhkan biaya sangat besar menghimpun koleksi local content Jawa Timur,
\end{abstract}

Kata Kunci : Local Content Jawa Timur. Implementasi. Kebijakan Publik. Undang-Undang Nomor 4 Tahun 1990

\section{PENDAHULUAN}

Konsekwensi logis dari perubahan di era globalisasi, menyebabkan kebutuhan masyarakat terhadap informasi semakin bervariatif, baik ragam dan bentuknya. Peran perpustakaan juga semakin berkembang, karena merupakan organisasi sebagai wadah yang berfungsi mengumpulkan, mengolah, mengemas, memelihara, melestarikan, menyajikan dan menyebarluaskan informasi kepada masyarakat.

$$
\text { Perpustakaan dapat dijadikan }
$$

sarana saling tukar-menukar, memperkaya, menguji dan memberi nilai tambah terhadap informasi untuk perkembangan jaman ke arah yang lebih baik lagi. Melalui perpustakaan pula setiap penemuan dan pemikiran baru dengan cepat menjadi milik bersama (Sutarno, 2004:2). Menurut Undang-Undang Republik Indonesia Nomor 43 Tahun 2007 Tentang Perpustakaan pada Bab I pasal 1, 
menyatakan bahwa perpustakaan ialah konstitusi pengelola koleksi karya tulis, karya cetak dan atau karya rekam secara profesional dengan sistem yang baku guna memenuhi kebutuhan pendidikan, penelitian, pelestarian informasi dan rekreasi bagi pemustaka.

Perpustakaan Umum Daerah di propinsi Jawa Timur, pada umumnya juga menyediakan koleksi local content Jawa Timur. Informasi yang termuat dalam koleksi local content Jawa Timur adalah bermacam-macam informasi mengenai Jawa Timur. Ketersediaan koleksi local content Jawa Timur itu, berasal dari semua terbitan di lingkungan Provinsi Jawa Timur yang terdiri dari 29 kabupaten dan 9 kota, termasuk juga laporan penelitian. Kebijakan dalam pengadaan, pengumpulan dan pengembangan koleksi local content ditujukan untuk dapat memenuhi kebutuhan pemustaka. Adapun sebagai dasar pijakan untuk pengadaan, pengumpulan dan pengembangan koleksi local content itu, Perpustakaan Umum Daerah berpedoman pada Undang-Undang Nomor 4 Tahun 1990 tentang Serah Simpan Karya Cetak dan Karya Rekam.

Undang-Undang Nomor 4 Tahun 1990, merupakan bukti dan langkah konkrit negara dalam menguatkan serta menegaskan bahwa perpustakaan sebagai pilar atau benteng peradaban bangsa.
Kemudian disusul dengan Peraturan Pemerintah Nomor 70 Tahun 1991 tentang Pelaksanaan Serah Simpan Karya Cetak dan Karya Rekam. Disamping itu juga diterbitkannya Peraturan Pemerintah Nomor 23 Tahun 1999 tentang Pelaksanaan Serah Simpan Dan Pengeloaan Karya Rekam Film Cerita Atau Film Dokumenter. Selanjutnya Undang-Undang Nomor 4 Tahun 1990 sangat lazim disebut sebagai UndangUndang Deposit atau Undang-Undang Serah Simpan. Adapun Visi dari UndangUndang Serah Simpan adalah mewujudkan koleksi nasional dan melestarikannya, sebagai hasil budaya bangsa dalam rangka mencerdaskan kehidupan bangsa, maka Perpustakaan Nasional dan Perpustakaan Umum Daerah diberikan tugas dan wewenang untuk menghimpun, mengelolah, menyimpan, melestarikan dan mendayagunakan semua karya cetak dan karya rekam.

Realitasnya koleksi local content yang tersedia pada Perpustakaan Umum Daerah di Provinsi Jawa Timur, masih dirasakan kurang memadai dalam memenuhi kebutuhan informasi pemustaka. Kebutuhan informasi yang semakin meningkat akan terus menuntut perpustakaan untuk selalu berperan aktif dalam menyediakan pengadaan koleksi local content Jawa Timur dengan 
melakukan usaha semaksimalnya. Adapun usaha itu dilakukan dengan mengimplementasikan Undang-undang Nomor 4 Tahun 1990 secara lebih optimal lagi, mengingat sudah lebih dari 25 tahun, ketersediaan koleksi local content Jawa Timur masih dirasakan kurang memenuhi kebutuhan informasi pemustaka.

Bertitik tolak dari latar belakang yang telah terurai di atas, maka tujuan dalam penulisan kajian yang dilakukan ini, adalah merupakan upaya untuk mengetahui tentang: (1).Arti penting koleksi local content Jawa Timur (2). implementasi Undang-Undang Nomor 4 Tahun 1990 tentang serah simpan karya cetak dan karya rekam koleksi local content di perpustakaan umum daerah di Provinsi Jawa Timur. (3). Kendala apa saja yang dihadapi dalam pelaksanaan Undang-Undang Nomor 4 Tahun 1990 tentang serah simpan karya cetak dan rekam koleksi local content di Perpustakaan Umum Daerah di Provinsi Jawa Timur serta solusi pemecahannya serta prospek ke depan?

\section{KAJIAN PUSTAKA/TEORI}

\section{A. Perpustakaan Umum Daerah.}

Perpustakaan Umum Daerah, adalah perpustakaan yang memberikan pelayanan jasa informasi pada kepuasan pemustaka. Aktivitas pekerjaannya berdasarkan pada kebijakan publik yang dikeluarkan oleh negara. Adapun Fokus atau sasaran tindakan kerja selalu mengutamakan pemenuhan terhadap indeks pelayanan publik yang telah digariskan dalam kebijakan publik. Koleksi local content Jawa Timur semakin menjadi kebutuhan mendesak, untuk dihimpun dan didayagunakan, sehingga sangat membantu dalam memenuhi kebutuhan informasi pemustaka tentang khasanah budaya dn peradaban Jawa Timur.

Menurut Sulistyo Basuki (2001), perpustakaan umum adalah perpustakaan yang diselenggarakan oleh dana umum dengan tujuan melayani masyarakat umum. Adapun ciri-ciri perpustakaan umum adalah sebagai berikut : (a). Terbuka untuk umum artinya terbuka bagi siapa saja tanpa memandang jenis kelamin, agama, kepercayaan, ras, usia, pandangan polotik dan pekerjaan. (b). Dibiayai oleh dana umum adalah dana yang berasal dari masyarakat, biasanya dikumpulkan melalui pajak dan dikelola oleh pemerintah. (c). Jasa yang diberikan pada hakekatnya bersifat cuma-cuma. Jasa yang diberikan mencakup referral artinya jasa memberikan informasi, peminjaman, konsultasi, studi, sedangkan untuk keanggotaannya bersifat cuma-cuma.

Perpustakaan umum daerah di

Program Studi Perpustakaan dan Sains Informasi Universitas Wijaya Kusuma Surabaya 
provinsi Jawa Timur merupakan pusat informasi perpustakaan-perpustakaan di daerah kabupaten/kota madya, disamping itu juga sebagai pusat deposit daerah, pusat pembelajaran daerah, pusat penelitian daerah, pusat informasi, dan memberikan layanan informasi yang dimanfaatkan oleh masyarakat luas. Dalam Undang-Undang Nomor 43 Tahun 2007 pasal 8 menyatakan bahwa:

$\begin{array}{lrr}\text { "Pemerintah } & \text { Provinsi dan } \\ \text { Pemerintah } & \text { Kabupaten/Kota } \\ \text { berkewajiban } & \text { dalam } \\ \text { menyelenggarakan } & \text { dan } \\ \text { menyelenggarakan } & \text { perpustakaan } \\ \text { umum daerah } & \text { berdasarkan } \\ \text { kekhasan daerah sebagai pusat } \\ \text { penelitian dan rujukan tentang } \\ \text { kebudayaan daerah di wilayahnya." }\end{array}$

Penghimpunan koleksi local content disesuaikan dengan kekhasan daerah, sebagai pusat informasi dan penelitian serta rujukan tentang kebudayaan daerah. Pentingnya menyediakan koleksi local content, bertujuan untuk menumbuhkembangkan nasionalisme dan sebagai sarana potensial dalam mempertahankan kebudayaan, tradisi, nilai-nilai lokal, kearifan lokal dan indikator referensi dalam bertindak, berkarya dan berkreasi.

Perpustakaan umum secara optimal senantiasa mengutamakan kepentingan publik dan berkaitan dengan pelayanan publik, maka perpustakaan umum memiliki beberapa fungsi utama yaitu : (1). Fungsi rekreasi. Fungsi ini menunjuk bahwa perpustakaan dimanfaatkan menciptakan kehidupan seimbang antara jasmani dan rohani. Rekreasi dapat dilakukan dengan memanfaatkan berbagai macam bacaan yang ada, sehingga menimbulkan kreativitas dan memperoleh hiburan segar bersifat positif. (2). Fungsi informasi. Perpustakaan sebagai pusat informasi menyediakan berbagai macam informasi yang meliputi bahan cetak, rekam maupun koleksi lainnya. Pemanfaatan perpustakaan menyebabkan pemustaka dapat memperoleh ide-ide baru berbagai bidang ilmu pengetahuan. (3). Fungsi pendidikan. Perpustakaan merukupakan sarana pendidikan nonformal dan informal, yang bermanfaat bagi pemustaka untuk mendidik diri sendiri, membangkitkan dan mengembangkan minat membaca untukpenguasaan ilmu pengetahuan dan teknologi (4). Fungsi penelitian. Perpustakaan menyediakan informasi untuk menunjang kegiatan penelitian, dengan melengkapi dan menyediakan berbagai jenis informasi. (5). Fungsi deposit. Perpustakaan berkewajiban menghimpun, menyimpan dan melestarikan semua karya cetak dan rekam yang diterbitkan di Indonesia. (6). Fungsi kebudayaan. Perpustakaan sebagai 
tempat untuk pendidikan guna menumbuhkembangkan apresiasi budaya masyarakat. Pemanfaatan jasa informasi perpustakaan dapat membangkitkan minat dan kreativitas terhadap kesenian dan kebudayaan masyarakat.

\section{B. Koleksi Local Content}

Menurut pendapat Liaw (2005:1) yang menyatakan bahwa koleksi local content adalah koleksi yang memiliki karakteristik lokal. Adapun yang dimaksud dengan karakteristik lokal yaitu informasi yangdiproduksi secara lokal dan memiliki kandugan informasi tentang suatu etnis lokal

(perorangan,kelompok,komunitas,institusi, geografi, budaya, dll). Jenis koleksi local content adalah koleksi buku, peta, cetakan, ilustrasi dan materi-materi lainnya yang berkaitan erat dengan lokasi khusus. Sedangkan menurut Sulistyo Basuki (2001) menyatakan bahwa muatan lokal merupakan buku dan cantuman tertulis lainnya yang berkaitan dengan sebuah kawasan geografis yang diterbitkan oleh sebuah badan korporasi, perorangan, baik tersedia di toko atau merupakan literatur kelabu.

Koleksi local content, apabila dikelolah dengan baik maka dapat memiliki potensi yang besar bagi peran perpustakaan untuk menjadi pusat perhatian masyarakat dan pemerintah dalam melestarikan budaya daerah. Adapun potensi yang terdapat dalam local content antara lain; (1). Potensi kearifan lokal merupakan kekayaan kekhasan atau karakteristika nilai-nilai dan norma-norma masyarakat daerah. (2). Potensi wilayah merupakan kekayaan suatu wilayah yang memiliki bentuk budya dan sejarah yang khas, pariwisata, dan lain-lain. (3). Potensi perekonomian merupakan bentuk perekonomian lokal dengan dihasilkan dari pengrajinan arca, batik, tas, sepatu dan lain-lain. (4). Potensi perusahaan lokal seperti hasil produknya, sejarah perkembangan perusahaan dan lain-lain. (5). Potensi kuliner yang memiliki beraagam jenis masakan yang menjadi ciri khas lokalitas daerah. (6). Potensi pendidikan tinggi lokal, yang mempuyai peneliti, dosen, pustakawan, tenaga non edukasi, dan para akademisi, di mana menghasilkan berbagai skripsi, tesis, disertasi, karya penelitian,, karya pemikiran, bahan perkuliahan, sejarah, dan sebagainya, yang telah dilaksanakan oleh lembaga perguruan tinggi dan didokumentasikan sebagai karya cetak ataupun karya rekam (7). Potensi lokal lainnya, yang mempunyai nilai tambah untuk perekonomian masyarakat antara lain; daerah home industri, kawasan pariwisata, dan lain-lain 


\section{Koleksi Local Content Jawa Timur}

Koleksi local content dapat dijadikan sumber informasi yang relevan bagi pemustaka dikarenakan memuat informasi khusus tentang sejarah, kawasan industri dan home industri, tempat perbelanjaan, daerah wisata kuliner, kebudayaan, pariwisata, perekonomian, institusi, organisasi maupun masyarakat. Muatan koleksi local content berisikan sumber-sumber informasi yang khas dan unik, serta memiliki nilai yang tinggi warisan budaya lokal. Sebagaimana local content menurut Sulistyo Basuki (2001) adalah " koleksi buku, peta, cetakan, ilustrasi dan materi lainnya yang berkaitan dengan lokasi khusus".

Sedemikian penting dan potensi yang terkandung dalam koleksi local content, maka sangat perlu untuk menghimpun, mengelola, melestarikan, mendesiminasikan dan mendisrtibusikan informasi kepada masyarakat. Upaya pengelolaan dan menjaga ketersediaan koleksi local content sangat memerlukan berbagai kebijakkan perpustakaan dan pemerintah. Guna menjaga ketersediaan koleksi local content, perpustakaan perlu melakukan penyimpanan koleksi sesuai dengan kondisi tiap koleksi. Penyimpanan koleksi yang baik dan bersih, merupakan cara untuk menjaga dan mencegah kerusakan dan kehilangan serta paling utama adanya pelestarian koleksi local content, baik dari segi isi informasi maupun bentuk fisiknya

Pengadaan koleksi setiap tahunnya selalu ditingkatkan, agar ketersediaan koleksi local content selalu terjaga baik. Upaya perpustakaan dalam pengadaan koleksi local content, sangat memerlukan dasar hukum sebagai landasan yang kuat, sehingga dapat melaksanakan usaha yang optimal. Adapun cara untuk pengadaan koleksi local content, maka Badan Perpustakaan dan Kearsipan Provinsi Jawa Timur sangat perlu mengimplementasi Undang-Undang Nomor 4 Tahun 1990 secara optimal.

\section{Pengertian Kebijakan Publik}

Santoso (1998:4-8) memisahkan berbagai pandangan tentang kebijakan publik ke dalam dua kelompok. Pemikiran pertama menyatakan bahwa kebijakan publik sama dengan tindakanyang dilakukan oleh pemerintah, sebagaimana yang diungkapkan oleh Thomas K. Dye (1978: 3) bahwa " Public policy is whatever government chose to do or not to do " (ataupun yang dipilih oleh pemerintah untuk dilakukan atau tidak dilakukan).

Pengertian kebijakan publik hanya dari satu sudut pandangsaja yakni pemerintah, tetapi pendapat Thomas Day, 
memberikan nuansa baru tentang konsep kebijakan publilk. Kebijakan bukan merupakan keingin pemerintah saja, melainkan masyarakat juga memiliki keinginan. Prinsipnya kebijakan publik adalah mencangkup "apa” yang dilakukan, "mengapa" mereka melakukanya, dan "bagaimana" akibatnya (Afan Gffar, 1991: 7). Di pihak lain Edward C George III (1980: 2) menyatakan bahwa tidak ada definisi yang tunggal dari kebijakan public, "what government say and do, or not to do".

Dari definisi di atas, maka kebijakan publik meliputi segala sesuatu yang dinyatakan dan dilakukan atau tidak dilakukan oleh Pemerintah. Disamping itu kebijakan publik adalah juga kebijakankebijakan yang dibuat oleh badan-badan dan pejabat-pejabat pemerintah (James E. Anderson, 1979: 3). Imbas pengertian dari pandangan ini adalah bahwa kebijakan publik : (1). Lebih merupakan tindakan yang mengarah pada tujuan daripada sebagai perilaku antau tindakan yang kebetulan ; (2). Pada hakekatnya terdiri atas tindakan-tindakan yang saling terkait; (3). Bersangkutan dengan apa yang benarbenar dilakukan oleh pemerintah dalam bidang tertentu atau bahkan merupakan apa yang pemerintah maksud atau melakukan sesuatu atau menyatakan melakukan sesuatu; (4). Bisa bersifat

positif yang berarti merupakan beberapa bentuk tindakan (langkah) pemerintah mengenai masalah tertentu, dan bersifat negative yang berarti merupakan keputusan pemerintah untuk tidak melakukan ssesuatu; (5). Kebijakan publik setidak-tidaknya dalam arti positif didasarkan atau selalu dilandaskan pada peraturan undang-undang yang bersifat memaksa (otoratif).

Pandangan lainnya dari kebijakan publik, melihat kebijakan publik sebagai keputusan yang mempunyai tujuan dan maksud tertentu, berupa serangkaian instruksi dan pembuatan keputusan kepada pelaksana kebijakan yang menjelaskan tujuan dan cara mencapai tujuan. Hal ini sejalan dengan apa yang dikemukakan oleh Soebakti dalam Samodro Wibowo (1994: 190) bahwa kebijakan negara merupakan bagian keputusan politik yang berupa progam perilaku untuk mencapai tujuan masyarakat negara.

Dari beberapa pandangan tentang kebijakan negara tersebut, dengan mengikuti paham bahwa kebijakan negara itu adalah serangkai tindakan yang ditetapkan dan dilaksanakan oleh pemerintah, yang mempunyai tujuan atau berorientasi pada tujuan tertentu demi kepentingan seluruh rakyat, maka M. Irfan Islamy (1997:20) mengemukakan beberapa elemen penting dalam kebijakan 
publik, yaitu : (1). Bahwa kebijakan publik itu dalam bentuk perdanya berupa penertapan tindakan-tindakan pemerintah; (2). Bahwa kebijakan publik itu tidak cukup hanya dinyatakan tetapi dilaksanakan dalam bentuk yang nyata; (3). Bahwa kebijakan publik, baik untuk melakukan sesuatu ataupun tidak melakukan sesuatu itu mempunyai dan dilandasi maksud dan tujuan tertentu; (4). Bahwa kebijakan publik itu harus senantiasa ditujukan bagi kepentingan seluruh anggota masyarakat;

\section{E. Pengertian Implementasi}

Sebagaimana yang diungkapkan secara nyata oleh Charles O. Jones (1991), bahwa implementasi sebagai " getting the job done" dan "doing it". Dibalik kesederhanaan rumusan itu, berarti bahwa implementasi kebijakan merupakan suatu prosses kebijakan yang dapat dilakukan dengan mudah. Naman pelaksanannya, menuntut persyaratan yang nyata yaitu: adanya pelaksana, uang dan kemampuan organisasi sering disebut dengan resources. Sedangkan Van Meter dan Horn (1978:70) telah memberikan definisi implementasi kebijakan sebagai berikut:

"policy implemtation encompasses those actions by public and private individuals (and groups) that are directed at the achievement of goals and objectives set forth in prior policy decisions. “

Pemaknaan definisi tersebut bahwa implementasi kebijakan adalah tindakantindakan yang dilakukan oleh individuindividu, kelompok, pemerintah dan swasta yang diarahkan pada pencaipaian tujuan dan sasaran yang ditetapkan. Tindakan-tindakan ini, pada suatu saat berusaha untuk mentrasformasikan keputusan-keputusan menjadi pola-pola operasioanal, serta melanjutkan usahausaha tersebut untuk mencai perubahan, baik yang besar mamupun yang kecil, yang diamatkan oleh keputusan kebijakan.

Selanjutnya Mazmaian dan Sabatier (dalam Solichin Abdul Wahab, 1997:65) menjelaskan lebih lanjut tentang konsep implementasi kebijakan sebagaaaimana berikut :

"Memahami apa yang senyatanya terjadi sesudah progam dinyatakan berlaku atau dirumuskan merupakan focus perhatian implementasi kebijakan, yaitu kejadian- kejadian atau kegiatan yang timbul setelah disahkannya pedoman-pedoman kebijakan negara, yaitu mencangkup baik usaha-usaha untuk mengadministrasikannya maupun untuk meninbulkan akibat/dampak nyata pada masyarakat atau kejadian-kejadian."

Tampak jelas bahwa implementasi kebijakan tidak hanya terbatas pada tindakan atau perilaku alternative atau unit birokrasi yang bertanggung jawab untuk 
melaksanakan progam dan menimbulkan kepatuhan dari targrt group, namun lebih dari itu juga berlanjut dengan jaringan kekuatan politik social ekonomi yang berpengaruh pada perilaku semua pihak yang terlibat dan pada akhirnya terdapat dampak yang diharapkan maupun yang tidak diharapkan. Jadi implementasi kebijakan akan selalu berkaitan dengan perencanaan penentuan waktu dan pengawasan, sedangkan menurut Mazmanian dan Sabatier dalam Solihin Abdul Wahab, (1991) bahwa mempelajari masalah implementasi kebijakan berarti berusaha memahami apa yang senyatanya terjadi sesudah suatu program diberlakukan atau dirumuskan. Yakni peristiwa-peristiwa dan kegiatan-kegiatan yang terjadi setelah proses pengesahan kebijakan baik, yang menyangkut usahausaha untuk mengadministrasi maupun usaha untuk memberikan dampak tertentu pada masyarakat.

\section{F. Factor-faktor yang Mempengaruhi} Implementasi Kebijakan.

Standard dan tujuan kebijakan berpengaruh tidak langsung terhadap disposisi para pelaksana melalui aktivitas komunikasi antar organisasi. Jelas respon para pelaksana terhadap suatu kebijakan didasarkan pada respon para pelaksana, terhadap suatu kebijakan didasarkan pada persepsi dan interpretasi mereka terhadap tujuan kebijakan tersebut. Walaupun demikian, hal ini bukan berarti bahwa komunikasi yang baik akan menyeimbangkan disposisi yang baik atau positif diantara para pelaksana. Standard dan tujuan juga mempunyai dampak yang tidak langsung terhadap disposisi para pelaksana melalui aktivitas penguatan atau pengabsahan. Hubungan antar sumber daya (resources) dengan kondisi social, ekonomi dan politik dalam batas wilayah organisasi tertentu dapat dikemukakan bahwa tersedianya dana dan sumber lain dapat menimbulkan tuntutan dari warga masyarakat swasta, kelompok kepentingan yang terorganisir untuk ikut berperan dalam melaksanakan dan mensukseskan suatu kebijakan. Jelaskan prospek keuntungan pada suatu progam kebijakan dapat menyebabkan kelompok lain untuk berperan sreta secara maksimal dalam melaksanakan suatu progam kebijakan. Sebagaimana menurut pandangan George C. Edward III dalam implementing public policy $(1980,111)$ ada empat factor yang berpengaruh terhadap keberhasilan atau kegagalan implementasi sesuatu kebijakan, yaitu factor sumberdaya, birokrasi, komunikasi, dan disposisi. 


\section{Factor sumberdaya (resources)}

Factor sumberdaya mempunyai peranan penting dalam implementasi kebijakan, karena jelas dan konsistennya ketentuan-ketentuan atau aturan-aturan suatu kebijakan jika para personil yang bertanggung jawab mengimpelementasikan kebijkan, kurang mempunyai sumber-sumber untuk melakukan pekerjaan secara efektif, maka implementasi kebijakan tersebut tidak akan bisa efektif. Sumber-sumber dalam implementasi kebijakan yang dimaksud antara lain mencakup : (1). Staf yang mempunyai kemampuan dan keahlian untuk dapat melaksanakan tugas; (2). Perintah (3). Anjuran atasan atau pimpinan. (4). Adanya kelayakan antara jumlah staf yang dibutuhkan dan keahlian yang dimiliki dengan tugas yang akan dikerjakan. (5). Dana untuk dapat membiayai operasionalisasi implementasi kebijakan tersebut. (6). informasi yang relevan dan mencukupi tentang bagaimana cara mengimplementasikan suatu kebijakan, (7). kesanggupan dari berbagai pihak yang terlibat dalam implementasi atau kebijakan tersebut

\section{Struktur birokrasi}

Kendatipun sumber-sumber untuk mengimpementasi suatu kebijakan, sudah mencukupi dan para impelementor mengetahui apa dan bagaimana cara melakukannya, serta mereka mempunyai keinginan untuk melakukannya, implementasi bisa jadi masih belum efektif, karena ketidak efisienan struktur birokrasi yang ada.

\section{Factor kominikasi}

Komunikasi adalah merupakan suatu aktivitas manusia untuk dapat menyampaikan apa yang menjadi pemikiran, perasaannya, dan harapannya kepada pihak lain.. Factor komunikasi dianggap sebagai factor yang penting, karena setiap proses aktivitas manusia dan sumberdaya senantiasa berkaitan erat dengan permasalahan interaksi sosial itu dilakukan

\section{Faktor disposisi}

Disposisi ini diartikan sebagai sikap para pelaksana untuk mengimplementasikan kebijakan. Dalam implementasi kebijakan, jika ingin berhasil secara efektif dan efesian, para implementor tidak hanya harus mengetahui apa yang harus mereka lakukan dan mempunyai kemampuan untuk implementasi kebijakan tersebut, tetapi mereka juga harus mempunyai kemauan untuk mengimplentasikan kebijakan tersebut. 


\section{METODE KAJIAN}

\section{A. Obyek Kajian.}

Obyek kajian bertumpu pada implementasi Undang-Undang Nomor 4 Tahun 1990 dengan melakukan kajian mendalam tentang content kebijakan publik, implementasi, koleksi local conten. Penguasan dan pemahaman terhadap implentasi Undang-Undang Nomor 4 Tahun 1990 adalah sangat penting, karena erat berkaitan dengan perlindungan dan pengembangan peradaban bangsa dan negara Indonesia.

\section{B. Ruang Lingkup Dan Fokus Kajian.}

Ruang lingkup kajian berfokus pada perwujudan manajemen implentasi Undang-Undang Nomor 4 Tahun 1990. Tujuan utama perpustakaan adalah memberikan pelayanan prima bagi pemustaka. Adapun fungsi kultural perpustakaan adalah menghimpun dan melestarikan berbagai karya khasanah budaya bangsa, sehingga sangat penting untuk memiliki ketersediaan koleksi local content.

\section{Pendekatan Dan Metode Kajian} Adapun pendekatan kajian ini secara metodologis disebut dengan pendekatan sejarah (historical approach) dengan ciri yang sangat dominan penyelidikan yang kritis melalui pemanfaatan data primer sebagai sumber informasi primer. Metode kajian yang digunakan adalah kajian perpustakaan atau studi pustaka (library research) dengan membaca berbagai literatur dengan bersubyekkan kepemimpinan, motivasi dan produktivitas kerja dalam organisasi perpustakaan.

\section{Analisis Kajian}

Analisis kajian dilakukan dengan menggunakan analisa diskriptif kualitatif. Adapun sumber analisa berasal dari kajian bahan-bahan pustaka yang berisi teoritis, penelitian dan kajian bukan penelitian. Dilakukan juga content analysis, untuk menganalisa terhadap makna yang terkandung dalam keseluruhan konsep implementasi Undang-Undang Nomor 4 Tahun 1990 dan local contet Jawa Timur. Observasi mendalam sehari-hari di perpustakaan digunakan untuk mendukung konstruksi teoritis.

\section{PEMBAHASAN}

\section{A. Implementasi Undang-Undang Nomor 4 Tahun 1990 Tentang Serah Simpan Karya Cetak dan Karya Rekam}

Pelayanan publik juga merupakan bagian yang krusial dalam praktek negara demokrasi, karena demokrasi sebagai 
konsep hanya dapat dirasakan dalam kualitas layanan yang diberikan oleh pemerintah kepada rakyatnya. Tingkat heterogenitas dan penyebaran yang luas, maka sangat rentan bagi pemerintahan dapat memenuhi kebutuhan layanan masyarakat sesuai dengan tingkat kebutuhan apalagi tingkat kepuasan rakyat. Dalam konteks ini layanan menjadi tolok ukur penting untuk melihat perjalanan demokrasi dan desentralisasi, guna melihat kemampuan dari pemerintah dan pemerintah daerah, dalam melakukan transaksi sosial yang paling nyata dalam kehidupan sehari-hari yaitu layanan publik.

Pemberian layanan publik perlu diperhatikan tingkat pencapaian kinerjanya, yang meliputi layanan yang adil, kesiapan kerja dan mekanisme kerja (readiness), harga terjangkau (affordable price), prosedur sederhana dan dapat dipastikan waktu penyelesaiannya. Sedangkan penerima layanan publik, harus mempunyai pemahaman dan reaktif terhadap layanan tak berkualitas yang muncul dalam praktik penyelenggaraan layanan publik. Peran aktif masyarakat baik dalam mengawasi, menyampaikan keluhan terhadap praktik penyelenggaraan layanan publik, menjadi faktor penting sebagai umpan balik untuk perbaikan kualitas layanan publik sesuai standar yang ditetapkan. Dalam prosesnya, Pemerintah Daerah propinsi dan kabupaten/kota mendapat kesempatan dapat menentukan sendiri fokus pembangunan daerah dengan mengoptimalkan sumber daya dan kemampuan perangkat daerah. Perangkat daerah yang sangat terkait dengan penyebaran informasi adalah perpustakaan daerah, sebagai badan yang selama ini hanya dianggap sebagai sumber bacaan umum, terutama yang bersifat hiburan dan sering dimarginalkan. Pada konsep pengembangan dan pembangunan daerah, perpustakaan dapat lebih diintensifkan fungsinya, sebagai salah satu sumber informasi pembangunan daerah, dengan memanfaatkan berbagai sistem serta teknologi informasi komunikasi (ICT), sehingga sangat memungkinkan transfer informasi yang lebih cepat, murah, dan efektif. Fungsi penyebarluasan informasi, kemudian dapat dikembangkan dan diintensifkan sehingga dapat memberikan nilai tambah yang positif bagi eksistensi perpustakaan.

Pelayanan jasa informasi menjadi semakin krusial, tatkala prosedur pemberian layanan tersebut tidak dibakukan secara komprehensif dan tidak ditetapkan dalam suatu standar pelayanan yang baik. Demi terlaksananya pelayanan jasa informasi maka ketersediaan koleksi local conten, harus dilakukan dengan 
berlandaskaan pada Undang-Undang

Nomor 4 Tahun 1990 sebagai acuan standar baku dan juga harus dilakukan koordinasi dengan berbagai pihak yang terkait.

Berdasarkan ketentuan UndangUndang Nomor 4 Tahun1990 tentang serah simpan karya cetak dan karya rekam, yang selanjutnya disebut sebagai Undang_undang Deposit dan koleksi yang dihimpun disebut koleksi deposit. UndangUndang ini, merupakan landasan hukum yang berintikan upaya mewujudkan Koleksi Nasional dan melestarikan hasil budaya bangsa. Perpustakaan Nasional RI berfungsi melaksanakan penghimpunan, penyimpanan, pelestrian dan pendayagunaan semua karya cetak dan karya rekam yang dihasilkan baik di Pusat maupun di Daerah.

Dalam pelaksanaan Undang-Undang RI Nomor 4 Tahun 1990 dan Peraturan Pemerintah Nomor 70 Tahun 1991, Perpustakaan Nasional RI melalui Pusat Deposit dan Konservasi dan Badan Perpustakaan dan Kearsipan Provinsi jawa Timur mendapat wewenang dalam melaksanakan pengelolaanya. Kewajiban untuk menyerahkan karya cetak dan karya rekam kepada Perpustakaan Nasional RI dan Badan Perpustakaan dan Kearsipan Provinsi Jawa Timur, terdiri dari karya cetak dan karya rekam. Dalam Peraturan
Pemerintah Nomor 70 Tahun 1991 tentang pelaksanaan Undang-Undang Nomor 4 Tahun1990, yang dimaksud dengan;

"Karya cetak adalah semua jenis terbitan dari setiap karya cetak atau artistik yang

Tercetak atau digandakan dalam system buku, majalah, surat kabar, peta, brosur

dan sejenisnya yang diperuntukan bagi umum. Sedangkan karya rekam adalah

rekaman dari setiap intelektual atau artitik yang direkam atau digandakan dalam

$\begin{array}{ccr}\text { sistem } & \text { lain } & \text { sesuai } \\ \text { perkembangan } & \text { teknologi } & \text { yang }\end{array}$
diperuntukan bagi umum”.

Adapun bagi mereka yang memiliki wajib menyerahkan karya cetak dan karya rekam adalah : (a). Penerbit; perseorangan, persekutuan, badan hukum baik milik negara maupun swasta yang menerbitkan karya cetak. (b). Pengusaha rekaman; perorangan, persekutuan, badan hukum baik milik negara maupun swasta yang menerbitkan karya rekam. (c). Warga negara Indonesia yang hasil karyanya diterbitkan atau direkam di luar negeri. (d). Orang / badan usaha yang memasukan karya cetak dan karya rekam mengenai Indonesia.

Mekanisme pelaksanaan penyerahan hasil karya cetak dan karya rekam, bagi penerbit wajib menyerahkan Karya Cetak: sebanyak 2 (dua) eksemplar dari setiap judul kepada Perpustakaan Nasional RI 
dan sebanyak 1 (satu) eksemplar dari setiap judul kepada Badan Perpustakaan Propinsi Jawa Timur. Bagi para pengusaha rekaman, wajib menyerahkan Karya Rekam: sebanyak 1 (satu) buah rekaman dari setiap judul kepada Perpustakaan Nasional RI serta sebanyak 1 (satu) buah rekaman dari setiap judul kepada Badan Arsip Perpustakaan Propinsi Jawa Timur. Sedangkan bagi perorangan yang memasukkan karya cetak dan karya rekam mengenai Indonesia dari Luar Negeri lebih dari 10 (sepuluh) buah setiap judulnya dengan makskud memperdagangkan, wajib menyerahkan 1 (satu) buah dari setiap judulnya kepada Perpustakaan Nasional RI.

Para Wajib serah simpan karya cetak dan karya rekam, wajib menyerahkan daftar judul karya kepada Perpustakaan Nasional RI dan Badan Arsip Perpustakaan Propinsi Jawa Timur sekali setiap 6 (enam) bulan. Adapun waktu penyerahan, selambat-lambatnya 3 (tiga) bulan bagi penerbit dan pengusaha rekaman, setelah karyanya selesai diterbitkan/diproses rekaman. Selambatlambatnya 1 (satu) bulan setelah karya cetak dan karya rekam diterima bagi yang memasukkan dari luar negeri.

Dalam Undang-Undang Nomor 4 Tahun 1990 disebutkan bahwa pelaksana di daerah adalah Perpustakaan Daerah
Provinsi, dalam hal ini adalah Badan Perpustakaan dan Kearsipan Provinsi Jawa Timur. Koleksi yang ada disebut koleksi deposit. Adapun kegiatan-kegiatan yang dilaksanakan dalam ruang deposit antara lain; (1). Melakukan pengeloaan (penghimpunan, pengumpulan, pengolahan dan penyajian) terbitan daerah baik tertulis, tercetak dan terekam sebagai koleksi daerah. (2). Melakukan pelacakan/hunting keberadaan koleksi bahan pustaka terbitan daerah. (3). Melakukan pendataan alamat-alamat penerbitan yang ada di Jawa Timur. (4). Melakukan pertemuan-pertemuan dengan penerbit swasta, pemerintah, pengusaha rekaman secara berkala. (5). Menyusun dan menerbiitkan daftar buku terbitan daerah atau biblografi daerah. (6). Menyusun dan menerbitkan daftar karya cetak dan karya rekam. (7). Menyebar luaskan informasi tentang koleksi deposit. (8). Melakukan pendayagunaan koleksi deposit untuk pengguna.

Koleksi local conten Jawa Timur merupakan bagian koleksi deposit Perpustakaan Umum Daerah di Provinsi Jawa Timur, koleksi tersebut meliputi antara lain; a). Karya Cetak : buku fiksi, buku non fiksi, buku rujukan, karya artistik, karya ilmiah yang dipublikasikan, majalah/buletin/jurnal, surat kabar/tabloid,

Program Studi Perpustakaan dan Sains Informasi Universitas Wijaya Kusuma Surabaya 
peta/brosur, karya cetak lain ditetapkan oleh Kepala Perpustakaan Nasional Republik Indonesia. b). Karya Rekam : kaset audio, kaset video, VCD/CD, rekaman bentuk lain sesuai dengan perkembangan teknologi. Terbitnya Undang-Undang Nomor 4 Tahun 1990 tentang serah simpan karya cetak dan rekam, telah dapat memberikan garis tegas dan landasan hukum yang kuat bagi Pemerintah Provinsi Jawa Timur untuk menghimpun seluruh hasil budaya bangsa. Undang-Undang Nomor 4 Tahun 1990, telah berlaku dan keberadaanya mengikat seluruh warga negara untuk ikut berperan aktif dalam usaha pelestarian hasil budaya bangsa. Ada kewajiban setiap warga negara yang berdomisili di Jawa Timur, yang menulis dan mengedarkan hasil tulisannya untuk menyerahkan 1 buah ke Badan Perpustakaan dan Kearsipan Provinsi Jawa Timur. Demikian juga terdapat kuwajiban bagi para penerbit swasta, pemerintah maupun pengusaha rekaman untuk menyerahkan1 buah dari semua hasil produksinya.

\section{B. Faktor-faltor Kendala Implentasi}

\section{Undang-Undang Nomor 4 Tahun 1990}

Dalam realitasnya pengadaan koleksi perpustakaan, terutama untuk penghimpunan, pengelolaan, penyajian, pelestarian dan pendayagunaan koleksi local content sangatlah membutuhkan biaya sangat besar. Adapun dana yang tersedia untuk kepentingan pengadaan koleksi perpustakaan sangat terbatas, akibatnya dalam ketersediaan koleksi local content di perpustakaan dirasakan belum mencukupi kebutuhan pemustaka,karena pengadaannya disesuaikan dengan anggaran yang ada.

Banyak sekali perpustakaan umum daerah yang memiliki keinginan terlibat secara aktif dalam pengadaan koleksi local content, akan tetapi belum ada Peraturan Daerah tentang serah simpan karya cetak dan karya rekam. Akibatnya dalam melakukan tindakan tidak memiliki dasar atau payung hukum yang kuat, sehingga pengadaan koleksi local content sangat terbatas. Payung hukum sangat diperlukan karena pengadaan koleksi local content sangat berkaitan dengan pihak penerbit swasta maupun pemerintah. Adanya payung hukum akan dapat menjamin pengadaan koleksi local content dapat terpenuhi, sehingga dapat memenuhi kebutuhan informasi pemustaka.

\section{PENUTUP}

1. Koleksi local conten sangat perlu untuk dikembangkan, dihimpun, dikelolah dengan baik, disimpan, dilestarikan dan didayagunakan semaksimal mungkin, karena sangat memiliki arti penting bagi

Program Studi Perpustakaan dan Sains Informasi Universitas Wijaya Kusuma Surabaya 
identitas daerah atau sesuai dengan

kekhasan daerah. Karya cetak dan karya rekam yang menyimpan karya-karya seni, budaya, kuliner, intelektual dan lain-lainnya, dapat memberikan nilai-nilai inspiratif dan kreatif yang dapat mendorong rasa kebanggaan terhadap budaya daerah. Tidak sedikit budaya daerah berperan serta dalam menyumbang pengembangan budaya nasional secara luas.

2. Perpustakaan Umum Daerah di Provinsi Jawa Timur, dalam mengimplementasikan UndangUndang Nomor 4 Tahun 1990 ,tentang Serah Simpan Karya Cetak dan Karya Rekam untuk dapat penghimpunan, pengelolaan, penyimpanan, pelestarian dan pendayagunaan koleksi local content sebagai khasanah budaya bangsa, telah dilaksanakan dengan cukup baik. Tersedianya koleksi local content yang cukup, akan dapat memberikan manfaat yang sangat besar bagi pemustaka yang membutuhkannya.

3. Belum adanya Peraturan Daerah tentang serah simpan karya cetak dan rekam, sehingga sangat perlu diterbitkan Peraturan Daerah yang baru yang mengatur serah terima karya cetak dan rekam sesuai dengan kekhasan daerah.

4. Dibutuhkan biaya besar untuk menghimpun, mengelola, menyajikan, melestarikan dan mendayagunakan koleksi local content Jawa Timur, sedang dana yang tersedia pada umumnya sangat terbatas.

\section{DAFTAR PUSTAKA}

Abdul Wahab, Solichin. 1997. Analisis Kebijakan dari Formasi Ke Implementasi Kebiakan Negara. Bumi Aksara: Jakarta..

Anderson, James E. 1978, Publik Policy Marketing. Holt, Ronehert and Winston: New York.

Dye, Thomas K. 1988. Understanding Public Policy. New Jersey, Prentice Hall, Inc.

Edwards C George III. 1980. Implementasi Publik Policy. Congressional Quarterly Press, Washington DC p. 9-13.

Gaffar, Afan. 1991. Kebijakan Publik. Andi Offset: Yogyakarta

Indonesia. Undang-Undang, Peraturan. Perturam Pemerintah Republik Indonesia Nomor 70 Tahun 1991 Tentang Pelaksanaan UndangUndang Nomor 4 Tahun 1990 Tentang Serah Simpan Karya Cetak dan Karya Rekam, Jakarta: Perpustakaan Nasional.

Indonesia. Undang-Undang, Peraturan.

Program Studi Perpustakaan dan Sains Informasi Universitas Wijaya Kusuma Surabaya 
Undang-Undang Republik

Indonesia Nomor 4 Tahun 1990

Tetang Serah Simpan Karya Cetak

dan Karya Rekam, Jakarta: Perpustakaan Nasional.

Indonesia. Undang-Undang, Peraturan. Undang-Undang Nomor 43Tahun 2007 Tentang Perpustakaan, Jakarta: Perpustakaan Nasional.

Islamy, M. Irfan. 1992. Prinsip-prinsip Perumusan Kebijakan Negara. Bina Aksara: Jakarta

Jones, O. Charles. 1991. Pengantar Kebijakan Publik. Rinehert and Winston, New York.

Liauw, Toong Tjiek dan Aditya Nugraha.2005. Desa Informasi:Local Content Global Reach Seminar Internasional Council on Archives, Section on University and Research Institution Archives in Michigan State University, east lausing.MI, USA on September 6-9 tersedia di https://scholar.geogle.com.av/citati on?view op= view

Citation\&hl=en\&user $=$ UEZ2AAA

AJ\&citationfor view=UEZ2TCcAAAAJ:qjMakFH Dv7sC

Santoso, Amir. 1998. Analisa Kebijakan Publik dalam Jurnal Ilmu Politik Nomor 3, Gramedia, Jakarta.

Sulistyo, Basuki. 2001. Pengantar Ilmu Perpustakaan, Jakarta: Gramedia Pustaka Utama.

Sutarno,NS.2004. Manajemen Perpustakaan:Suatu Pendekatan Praktek, Jakarta: Samitra Media Utama

Van Meter, DS and CE van Horn, 1978, The Policy Implementation Process: A Conceptual Framework Administration and Society

Wibowo, Samodro, 1994, Kebijakan Publik Proses dan Analisis, Intermedia, Jakarta

Program Studi Perpustakaan dan Sains Informasi Universitas Wijaya Kusuma Surabaya 